\title{
The Impact of Family Governance on the Sustainability and Continuity of Family Businesses in Botswana
}

\author{
Ruramayi Tadu ${ }^{1} \&$ Douglas Chiguvi ${ }^{2}$ \\ ${ }^{1}$ Vice President, Academic Affairs \& Research, BA ISAGO, University, P. Bag 149, Gaborone, Botswana \\ ${ }^{2}$ Senior Lecturer, Marketing Programmes, Entrepreneurship Department, BA ISAGO University P. Bag 149, \\ Gaborone, Botswana \\ Correspondence: Douglas Chiguvi, Marketing Programmes, Entrepreneurship Department, BA ISAGO \\ University P. Bag 149, Gaborone, Botswana. E-mail: dchiguvi@gmail.com
}

Received: May 29, 2019 Accepted: November 8, 2019 Online Published: November 23, 2019

doi:10.5539/ijms.v11n4p113 URL: https://doi.org/10.5539/ijms.v11n4p113

\begin{abstract}
Academic discussion on corporate governance and its related issues are clearly visible in any country with active capital markets. This suggests that good governance is a crucial factor for ensuring economic development. Of concern is the lack of continuity after the first generation of ownership and control. However, few studies can be found relating to smaller family businesses. With the aim of contributing to this knowledge gap, this study aimed at identifying the impact of family governance on the sustainability and continuity of family businesses in Botswana. A sample of 144 family-owned businesses based in Gaborone and Francistown participated in the study. Pearson $r$ correlation was used to measure the relationship between the variables of the study. The results showed that there is a weak positive relationship between family governance and the sustainability and continuity of family businesses in Botswana. It was recommended that mechanisms must be put in place in order to enlighten the benefits of having Board of Directors and to implement effective governance structures and systems to sustain the businesses in the market beyond generations.
\end{abstract}

Keywords: small family businesses, family governance, sustainability, continuity

\section{Introduction}

The importance of small and medium enterprises (SMEs) throughout the world is well documented. These forms of businesses are the mainstay of many economies around the world. They are engines of economic growth, employment creation and wealth creation (Republic of Botswana, 2014, p. 9). The International Labour Organisation (ILO) (2017) estimates the unemployment rate of Botswana to be $19.6 \%$ and youth unemployment (15-35yrs) continues to be high at 25.2\% (Statistics Botswana, 2017, p. 2). According to Botswana Vision 2036, the country envisages to be a high-income export-led, diversified with sustainable growth driven by high levels of productivity (Botswana Vision, 2036). To prepare Botswana for "life after diamonds", the government developed a growth paradigm in its "Vision 2016" and "Vision 2036" strategy document, which suggests that the development of "new economy" skills will play an extremely important role in the country's future. Botswana is aiming to develop new engines of growth, supplementing the diamond industry with manufacturing, financial, and transport services, and transforming the country's entrepreneurship sector into a buoyant, productive, and innovative private sector led by entrepreneurs with cutting-edge skills. Entrepreneurship through SMEs has been identified by the government as a key strategy to deal with youth unemployment. The private sector was by far the largest employer with $44.6 \%$ of all employed persons (Statistics Botswana, 2017, p. 2). The government of Botswana has formulated its own policy on SMEs in the country and has expanded the definition of the term "SME" to include firms that may be classified as micro, small and medium enterprises. The Policy on Small, Medium and Micro Enterprises (SMMEs) in Botswana, Government Paper No. 1 of 1999, highlights several characteristics that the government uses to distinguish SMMEs from large firms (Botswana Institute for Policy Analysis [BIDPA], 1999). These characteristics are in alignment with the findings of the numerous studies which have been carried out across the world, and include turnover as an important element used in classifying SMMEs.

The problems and factors which impact on the long-term survival of a family owned business is a research area which is of interest to many scholars. This area has been widely studied to understand why between $5 \%$ and $13 \%$ of such firms only, survive to the third generation (Poza \& Daugherty, 2016). A study by Carlo, Francesco and 
Pramodita (2010, p. 322) analysed the term "continuity" and they sought to ascertain whether the term refers to the family name, the industry within which the business competes, the products it manufactures, the services it provides, or their markets. For the purposes of this study, governance is defined as a system of guidelines and protocols that manage the often competing and interrelated interests of various constituent groups. Family governance also provides a set of processes that enable families to determine a sense of direction, make decisions, and communicate the mission, vision and shared values to the various stakeholders. From a family perspective, such governance provides the family with a tool that helps them not only to recognise their own particular family dynamics, but also to manage them.

\section{Literature Review}

\subsection{Family Business}

Family businesses have become a topic of growing interest among scholars and policy makers at both international and local levels, particularly given the sector's contribution to the economies of countries worldwide. The increasingly volatile employment climate that prevails in many African settings today has increased the focus on small and medium enterprises as engines of economic growth and employment creation, and Botswana is no exception. The majority of family businesses are small to medium enterprises. For the purposes of this study, a family was defined as one where the family controls at least $20 \%$ of the shareholding and the business was under the management or control of the family management. According to Alderson (2015, p. 140), most family firms are SMEs, which are privately held. There is a natural tendency to assume that they face similar challenges as compared to non-family businesses of a like size. Valenti, Mayfield and Luce (2010, p. 66) note that SMEs are generally owned and managed by small, closely-knit groups of individuals who are often family members. Within the SME sector, family businesses are the dominant form of business organisations, as well as the key drivers of economies around the world (Tagiuri \& Davis, 1996; Bertrand \& Schoar, 2006; Memili, Singal, \& Barrédy, 2016). A family business is one that is owned by members of the same family who shape and/or pursue the formal or implicit vision of the business, which includes the intention of family members to hand the business over to the next generation; or else, the business has already been handed over to a family member to manage and/or control (Venter, 2003, p. 17). Studies by Kapteyn and Wah (2016) and Kasseeah (2016, p. 442) found that the majority of the private sector is still in its developmental stage. In addition, Kapteyn and Wah (2016) indicate that $83 \%$ of all private enterprises are to be found in the informal sector and that the majority of these are family-owned.

\subsection{Family Governance}

According to Berent-Braun and Uhlaner (2012, p. 104), family governance practices (FGP) are a means to enhance the entrepreneurship of the business-owning family. Family business governance practices are team building tools that not only enhance the effectiveness of the business-owning family, but also of the business it owns. Despite the increase in the literature devoted to family business governance over the last few years, there is nevertheless neither an overview nor consensus in relation to the way in which family governance may improve both the functioning of the family and the long-term success of the business (Suess, 2014, p. 138). The governance systems in the family business provide a mechanism in terms of which the business; the business family; and the management, are harmonised. The fundamental purpose of family governance is to make the existing and anticipated rewards and demands clear, to make participation in the business clear, to communicate opportunities for family involvement in the business, and to ease the flow of information (Suess, 2014, p. 139). In view of the fact that family governance is not legally obligatory; and there is no one particular standard rule, or rule which prescribes how family business affairs must be governed.

The three-circle model is the most traditional theoretical conceptual model for family businesses available. The model views the family business as comprising three main overlapping subsystems, namely, ownership, business and family (Gersick, Lansberg, Desjardins, \& Dunn, 1999). The growth and movement in each of the subsystems affect the governance issues in family businesses. In their article, Gersick et al. (1999, p. 289) argue that if families learn to manage periods of transition effectively, this, in turn, should dramatically increase the possibility of family business continuity. The model also highlights the need for the coexistence of multiple stakeholders in a family business environment. Angus (2005, p. 265) proposes a governance model comprising of principles, policies and practices, while Rodrigues and Marques (2013, p. 56) and Lungeanu and Ward (2012, p. 42) extend this governance model to include the governing bodies of family businesses, family meetings, family assemblies, family councils, sub-committees of councils, family agreements and the family office. It is imperative that the long-term interests of the family business shareholders are protected through the effective design of the governance structure in a family business so that the growth and continuity of the business may be ensured, and the 
family harmony and welfare preserved. If proper structures are in place, the probability of the actual implementation of good governance is enhanced (Adendorff, Boshoff, Court, \& Radloff, 2005, p. 34). Adendorff et al. (2005, p. 34) further state that the recognition of the role of family in entrepreneurship led family economists and family study researchers to attempt a simultaneous and comprehensive study of both the family and the family business.

Governance mechanisms such as succession plans, family protocols, and family councils help to regulate the economic and family relationships between active and passive family owners. Governance mechanisms improve transparency and also regulate the relationship between active and passive owners (Corbetta \& Salvato, 2004, p. 132). However, to date, there appears to be very little research into the empirical role of the effects of governance mechanisms on the survival and continuity of family businesses. Governance is a complicated issue in the context of family businesses because of the sometimes competing agendas of the family, ownership, and business management. Thus, there need to be a core structure that governs the family as well as the business entity. Governance enables the family to use understandable and transparent decision-making to handle both opportunities and the challenges of wealth (Goldhart \& Di-Furia, 2010, p. 8). Goldhart and Di-Furia (2010, p. 8) suggest a plethora of processes, including setting strategic goals, the maintenance of key relationships, safeguarding the health of the family, maintaining accountability, and recognising performance. A family governance structure creates the frameworks, policies and traditions that determine the parameters that govern how a family business is run. The literature ascribes great importance to the relationship between governance and the stage of the family business cycle. As the business grows and the family business evolves into the cousin phase, governance becomes critical to maintain the balance of the relationships. Lansberg (1999) argues that equal consideration and effort should be devoted to family business governance. The significance of family business governance is a function of both the size of the family, and the stage of business ownership. As the family business grows, the complexities arising from family and business imperatives become more complicated and conflict increases due to differences in goals and strategy (Alderson, 2015, p. 140). As family businesses expand from their entrepreneurial beginnings, they face unique performance and governance challenges (Casper, Dias, \& Elstrodt, 2010 , p. 1). Governance of both the family and business systems and processes are key determinants of a successful transition from the first generation to the next generation. Governance in the family business begins with a family's vision and mission. This sense of purpose, in turn, provides a roadmap a set of structure and processes that permit the family to make decisions over time as needed to ensure its survival as an economic unit (Brown, 2009, p. 45). In describing the relationship between the family business and the business family, Lambrecht $(2005$, p. 267) concludes that a family business can develop into a family dynasty only when it embraces sound governance as a fundamental principle; that is, the individual family member belongs to the family, which belongs to the business. As the business grows, families in business should be guided by the principles of sound governance to be related among themselves and with management. Ramachandran (2015) argues that the organisational challenges which family businesses when they grow transcend to an orbit, requires them to have additional expertise beyond the family domain.

\section{Research Methodology}

The study used a cross-sectional study and causal research design and adopted a quantitative research method. The targeted population consists of 243 family-owned businesses registered with either Business Botswana or the Local Enterprise Authority in 2017. This research used directional hypothesis and the main hypothesis of the study was that there is a positive relationship between family business governance and the sustainability and continuity of family businesses in Botswana. The research used the Pearson correlation coefficient (r) to determine the magnitude of the relationship, between existence of governance factors and sustainability and continuity of family businesses in Botswana. A total of 243 questionnaires were administered to family-owned businesses which had agreed to participate in the research. Of these, 167 completed questionnaires were returned with 144 being found to be usable. The researchers used a self-administered questionnaire to collect the data. SPSS was used in process the data and central tendency tables and hypothesis findings were used to present the study findings.

\section{Data Findings}

The sustainability and continuity of the family business was measured by the ability of the family business to transition beyond generations and to be both financially and systematically viable. It is against this background that a better understanding of the way in which governance structures and systems affect family businesses in Botswana should be fully explored for these forms of businesses to contribute to the economic diversification drive, and to deal with the growing youth unemployment as espoused by the Botswana Industrial Development Policy of 2014. 
Table 1. Item statistics: family governance

\begin{tabular}{|c|c|c|c|}
\hline Statement & Mean & Std. deviation & $\mathbf{N}$ \\
\hline The business has a Board of Directors & 2.50 & 1.544 & 143 \\
\hline The Board of Directors has a scheduled list of meetings per year & 2.51 & 1.528 & 143 \\
\hline There are outside board members on the Board of Directors & 2.28 & 1.410 & 143 \\
\hline The governance responsibilities in this business are clearly specified & 3.38 & 1.423 & 143 \\
\hline The business has clear governance rules & 3.62 & 1.251 & 143 \\
\hline The business has clear governance structures & 3.63 & 1.244 & 143 \\
\hline There is a family office which deals with family business matters & 3.22 & 1.423 & 143 \\
\hline There is a clear separation of family and business matters in the business & 3.54 & 1.269 & 143 \\
\hline $\begin{array}{l}\text { The business has a formal document that describes the relationship between the family and the } \\
\text { business }\end{array}$ & 3.18 & 1.337 & 143 \\
\hline When needed, the business draws on the expertise of outsiders (e.g., lawyers, accountants) & 3.89 & 1.301 & 143 \\
\hline The governance of the business is properly regulated & 3.83 & 1.114 & 143 \\
\hline The business asks outsiders to help with governance issues & 3.61 & 1.192 & 143 \\
\hline There are control measures in place in the business & 3.83 & 1.199 & 143 \\
\hline The business has an Advisory Board & 3.14 & 1.314 & 143 \\
\hline The business is adequately accountable to stakeholders & 3.79 & 1.288 & 143 \\
\hline There are systems in place to ensure legal compliance in the business & 3.94 & 1.351 & 143 \\
\hline
\end{tabular}

Table 1 shows that minimum scores were recorded for the items "There are outside Board members on the Board of Directors" $(\mathrm{m}=2.28)$, and "The business has a board of directors", $(\mathrm{m}=2.50)$. Small family businesses in Botswana do not realise the value added by having a Board of Directors. According to Vandebeek, Voordeckers, Lambrechts and Huybrechts (2016, p. 249), greater diversity in the boardroom seems beneficial for performance, owing to the increased availability of functional knowledge and skills. This study argues for a mechanism to enlighten SMEs of the benefits of having Board of Directors or Advisory Boards. A clear observation from this study was the higher mean $(\mathrm{m}=3.14)$ "The business has an Advisory Board", suggesting that family businesses viewed and accepted Advisory Boards more favourably than a Board of Directors. It can be inferred that Advisory Boards' role is less binding and controlling, yet providing the skills to augment family members. Family businesses need to take cognisance of what? Board service tasks entail; for example, building organisational reputation, networking, or advising management (Van den Heuvel, Van Gills, \& Voordeckers, 2006, p. 469; Wilson, Wright, \& Scholes, 2013, p. 1374).

Table 2. Relationship between family governance and the sustainability of family businesses

\begin{tabular}{llll}
\hline Statement & Governance structures & Sustainability of family businesses \\
\hline Governance structures & Pearson correlation & 1 & $.308^{* *}$ \\
& Sig. (2-tailed) & & .000 \\
& $\mathrm{~N}$ & 143 & 143 \\
Sustainability of family businesses & Pearson correlation & $.308^{* *}$ & 1 \\
& Sig. (2-tailed) & .000 & \\
& $\mathrm{~N}$ & 143 & 143 \\
\hline
\end{tabular}

Note. ${ }^{* *}$. Correlation is significant at the 0.01 level (2-tailed).

Table 2 shows the Pearson $r$ correlation test of family governance structures and the sustainability of family businesses. The analysis obtained the following value: $\mathrm{r}=0.308^{* *}$ and $\mathrm{p}=000$; hence, the null hypothesis $\mathrm{H} 1_{0}$ is rejected. A conclusion can therefore be made that there is a weak positive relationship $\left(r=0.308^{* *}\right)$ between family governance structures and the sustainability of family businesses. This means that governance structures are lowly/poorly recognised by family businesses. This can be inferred that family businesses must most in the first generation, controlled by the nuclear family have a low regard of governance structures. This implies that family business governance structures are positively related to family business sustainability. A good governance structure contributes to sustainable business development by enhancing the performance of the business and increasing its access to outside capital. The study also found that Advisory Boards were a potentially more important tool in the management of family businesses. They allow family businesses to have access to technical expertise without formal covenants. 


\section{Conclusion and Recommendations}

The researchers concluded that family governance structures are not yet fully adopted by family businesses in Botswana. The reason may be that most family businesses in Botswana are in the first generation, and, hence the need for family governance structures are less recognised. However, the study indicated that good family governance is necessary to promote the sustainability of family businesses. The researchers therefore recommend that good sound family governance structures are needed to ensure the sustainability of family businesses in Botswana. The results showed that there is a need of good family governance structures to promote the sustainability of family businesses in Botswana. The empirical results proved that the existence of governance structures affect the sustainability and survival of the family business.

\section{References}

Abouzaid, S. (2008). International Finance Corporation family business governance handbook (2nd ed.). Washington DC: International Finance Corporation.

Adendorff, C. M. (2004). The development of a cultural family business model of good corporate governance for Greek family businesses in South Africa. Unpublished Doctoral thesis, Rhodes University, Grahamstown.

Adendorff, C., Boshoff, C., Court, P., \& Radloff, S. (2005). The impact of planning on good governance practices in South African Greek family businesses. Management Dynamics, 14, 34-46.

Adendorff, C., Venter, E., \& Boshoff, C. (2008). The impact of family harmony on governance practices in South African Greek family businesses. Management Dynamics, 17(3), 28-44.

Alderson, K. (2015). Conflict management and resolution in family-owned businesses: A practitioner focused review, Journal of Family Business Management, 5(2), 140-156. https://doi.org/10.1108/JFBM-08-2015-0030

Angus. P. M. (2005). The family governance pyramid: From principles to practice. The Journal of Wealth Management, Summer, 7-13. https://doi.org/10.3905/jwm.2005.502661

Bendickson, J., Davis, P. E., Cowden, B. J., \& Liguori, E. W. (2015). Why small firms are different: Addressing varying needs from boards of directors. Journal of Small Business Strategy, 25(2), 41-57.

Berent-Braun, M. M., \& Uhlaner, L. M. (2012). Family governance practices and teambuilding: Paradox of the enterprising family. Small Business Economics, 38, 103-119. https://doi.org/10.1007/s11187-010-9269-4

Bertrand, M., \& Schoar, A. (2006). The role of family in family firms. The Journal of Economic Perspectives, 20(2), 73-96. https://doi.org/10.1257/jep.20.2.73

Blumentritt, T. (2006). The relationship between boards and planning in family businesses. Family Business Review, 19(1), 65-72. https://doi.org/10.1111/j.1741-6248.2006.00062.x

Brown, F. H. (2009). Growing beyond: Governance and the economic family. Family Business Review, Autumn, 9-13.

Casper, C., Dias, A. K., \& Elstrodt, H. (2010). The five attributes of enduring family business. Mckinsey Campany, January. Retrieved Novembe 26, 2016, from https://Mckinsey/com/business/functions/organisation/our-insights/the-five-attributes-of-enduring-family-b usinesses

Corbetta, G., \& Salvato, C. A. (2004). The board of directors in family firms: One size fits all? Family Business Review, 17(2), 119-134. https://doi.org/10.1111/j.1741-6248.2004.00008.x

Eckrich, C. J., \& McClure, J. (2013). Guidelines for effective family council. Family Business Review, May/June, $20-22$.

Gersick, K. E., Lansberg, I., Desjardins, M., \& Dunn, B. (1999). Stages and transitions: Managing change in the family business. Family Business Review, XII(4), 287-297. https://doi.org/10.1111/j.1741-6248.1999.00287.x

Goldhart, S., \& Di-Furia, J. (2010). Implementation of effective family governance structures. Journal of Practical Estate Planning, December/January, 7-9.

Kapteyn, A., \& Wah, S. H. (2016). Challenges to small and medium-size businesses in Myanmar: What are they and how do they know? Journal of Asian Economics, 47, 1-22. https://doi.org/10.1016/j.asieco.2016.08.004

Kasseeah, H. (2016). The performance of small firms: Does formality matter? Journal of Small Business and Entrepreneurship, 28(6), 431-448. https://doi.org/10.1080/08276331.2016.1202094 
Lambrecht, J. (2005). Multigenerational transition in family businesses: A new explanatory model. Family Business Review, XVIII(4), 267-282. https://doi.org/10.1111/j.1741-6248.2005.00048.x

Lansberg, I. (1999). Succeeding generations: Realizing the dream of families in business. Boston, MA: Harvard Business School Press.

Lungeanu, R., \& Ward, J. (2012). A governance-based typology of family foundations: The effect of generation stage and governance structure on family philanthropic activities. Family Business Review, 25(4), 409-424. https://doi.org/10.1177/0894486512444603

Memili, E., Singal, M., \& Barrédy, C. (2016). Family governance and family firm outcomes. Journal of Family Business Management, 6(2), 88-97. https://doi.org/10.1108/JFBM-05-2016-0010

Poza, E. J., \& Daugherty, M. S. (2016). Family business (4th ed.). Canada: South-Western Cengage Learning.

Ramachandran, K. (2015). The 10 commandments for family business. New Delhi, India: Sage Publications.

Rodrigues, J., \& Marques, M. A. A. (2013). Governance bodies of family business. Revista de Empresa Familiar, 3(1), 47-58. https://doi.org/10.24310/ejfbejfb.v3i1.4040

Stafford, K., Duncan, K. A., Dones, S. M. T., \& Winter, M. (1999). A research model of sustainable family business. Family Business Review, 12(3), 197-208. https://doi.org/10.1111/j.1741-6248.1999.00197.x

Statistics Botswana. (2017). Botswana Multi-topic Household Survey 2015/16: Economic Activity Statistics Brief. Department of Government Printing and Publishing.

Suáre, K. C., \& Santana-Martín, D. J. (2004). Governance in Spanish family business. International Journal of Entrepreneurial Behaviour and Research, 10(1/2), 141-163. https://doi.org/10.1108/13552550410521425

Suess, J. (2014). Family governance literature review and the development of a conceptual model. Family Business Strategy, 5, 138-155. https://doi.org/10.1016/j.jfbs.2014.02.001

Tagiuri, R., \& Davis, J. (1996). Bivalent attributes of the family. Family Business Review, 9(2), 199-209. https://doi.org/10.1111/j.1741-6248.1996.00199.x

Teksten, E. L., Moser, S. B., \& Elbert, D. J. (2005). Boards of directors for small business and small private corporations: The changing role, duties, and expectations. Management Research News, 28(7), 50-68. https://doi.org/10.1108/01409170510784887

Tillman, F. A. (1988). Commentary on legal liability: Organising the advisory council. Family Business Review, 1(3), 287-288. https://doi.org/10.1111/j.1741-6248.1988.00287.x

Valenti, M. A., Mayfield, C. O., \& Luce, R. A. (2010). What attracts directors to boards of small- and mid-sized companies? Journal of Small Business Strategy, 21(1), 65-82.

Van den Heuvel, J., Van Gills, A., \& Voordeckers, W. (2006). Board roles in small and medium-sized family businesses: Performance and importance. Corporate Governance: International Review, 14(5), 467-485. https://doi.org/10.1111/j.1467-8683.2006.00519.x

Venter, E. (2003). The succession process in small and medium sized family businesses in South Africa. $\mathrm{PhD}$ thesis, University of Port Elizabeth, Port Elizabeth.

Wilson, N., Wright, M., \& Scholes, L. (2013). Family business survival and the role of boards. Entrepreneurship Theory and Practice, 37(6), 1369-1389. https://doi.org/10.1111/etap.12071

\section{Copyrights}

Copyright for this article is retained by the author, with first publication rights granted to the journal.

This is an open-access article distributed under the terms and conditions of the Creative Commons Attribution license (http://creativecommons.org/licenses/by/4.0/). 